

\title{
Mechanical Mixtures of Me (Ni, Pd) Ce Oxides and Silica-Supported Heteropolyacids: Role and Optimal Concentration of Each Active Species in n-Hexane Isomerization
}

Robert Hubaut, Bouchta Ouled Ben Tayeb, Wenxing Kuang, Alain Rives, Michel Fournier

\section{To cite this version:}

Robert Hubaut, Bouchta Ouled Ben Tayeb, Wenxing Kuang, Alain Rives, Michel Fournier. Mechanical Mixtures of $\mathrm{Me}(\mathrm{Ni}, \mathrm{Pd}) \mathrm{Ce}$ Oxides and Silica-Supported Heteropolyacids: Role and Optimal Concentration of Each Active Species in n-Hexane Isomerization. Kinetics and Catalysis, 2006, 47, pp.20. 10.1134/S0023158406010046 . hal-00023862

\section{HAL Id: hal-00023862 https://hal.science/hal-00023862}

Submitted on 5 May 2006

HAL is a multi-disciplinary open access archive for the deposit and dissemination of scientific research documents, whether they are published or not. The documents may come from teaching and research institutions in France or abroad, or from public or private research centers.
L'archive ouverte pluridisciplinaire HAL, est destinée au dépôt et à la diffusion de documents scientifiques de niveau recherche, publiés ou non, émanant des établissements d'enseignement et de recherche français ou étrangers, des laboratoires publics ou privés. 


\title{
Mechanical mixtures of $\mathrm{Me}(\mathrm{Ni}, \mathrm{Pd}) \mathrm{Ce}$ oxides and silica-supported heteropolyacids : role and optimal content of each active species for n-hexane isomerization.
}

\author{
R.Hubaut ${ }^{*}$, B.Ouled Ben Tayeb ${ }^{*, * *}$, W.Kuang ${ }^{* * * *}$, A.Rives $^{*}$ and \\ M.Fournier*
}

\author{
*Laboratoire de Catalyse, UMR CNRS 8010, Bâtiment C 3, Université des Sciences et des \\ Technologies de Lille, 59655 Villeneuve d'Ascq Cedex \\ ** Département de chimie, Ecole Normale Supérieure de Fés, Maroc \\ ***3 Department of chemistry, University of Ottawa, 10 Marie Curie,Ottawa, Ontario, Canada \\ KIN 6N5 .
}

\begin{abstract}
Catalytic properties of silica-supported heteropolyacids (HPA) in a mechanical mixture with reduced $\mathrm{Me}-\mathrm{Ce}$ oxides $(\mathrm{Me}=\mathrm{Ni}, \mathrm{Pd})$ in $\mathrm{n}$-hexane isomerization are studied. The role of each component of the mixed oxides (Ce and, typically $\mathrm{Ni}$ and $\mathrm{Pd}$ ), and their optimum content were enlightened; cerium, not only is beneficial for eliminating or prevent, the coke deposition but is also effective for maintaining the Keggin structure of the highly-organized HPA during the reaction and, probably allows a better dispersion of the second metal species. Nickel and palladium, present as $\mathrm{Ni}^{0}$ and $\mathrm{Pd}^{0}$ reinforce the activation of the alkane which is difficult to obtain by directly attacking by an acid and, thus, enhance noticeably the activity of the catalyst. The best mechanical mixtures are obtained with 30-70 wt $\% \mathrm{NiCeO}-\mathrm{HPW} / \mathrm{SiO}_{2}$ and 50-50 wt $\% \mathrm{Pd}_{0.1} \mathrm{CeO}-\mathrm{HPW} / \mathrm{SiO}_{2}$. These mixtures have the highest efficiency for a $\mathrm{Ni} / \mathrm{Ni}+\mathrm{W}$ atomic ratio of 0.66 and a $\mathrm{Pd} / \mathrm{Pd}+\mathrm{W}$ ratio of 0.40 respectively. At last the conversion of $n$-hexane is in the order: HPW $>$ HSiW $>$ HBW which seems consistent with the order of their acid strength as claimed in the literature, but the isomerization selectivity appears slightly higher on HSiW.
\end{abstract}

\section{Introduction}

It is well-known that isomerization of light n-alkanes, which leads to branched alkanes, is easier on a bifunctional catalyst [1] by the help of a synergetic effect. Indeed, such a catalyst has hydrogenating/dehydrogenating and one another which is an acidic function. Both are working simultaneously as it is claimed that alkanes are dehydrogenated on metallic sites to the corresponding alkenes which are isomerized by acidic sites into branched alkenes; the latter are then hydrogenated into the branched alkanes again on the metallic sites. The mechanism can be different on mechanical mixtures, sometime called hybrid catalysts. As an example, Fujimoto et al [2] propose, on a physical mixture of $\mathrm{Pt} / \mathrm{SiO}_{2}$ and HZSM-5 powder, a mechanism based on a spillover phenomenon; the hydrogen gas being dissociated on the noble metal before it spills over onto the zeolite. The spill over phenomenon has been put in evidence later by infra-red spectroscopy [3]. The spill over of the reactives species between metal promoted oxide systems and acid sites was also proposed by Vasina et al [4]. 
Generally, the metallic species, the more often used is platinum. Concerning the solid acids, many catalysts, different of the chlorinated alumina, were tested (e.g. zeolites [5], sulfated zirconia [6], tungsten/molybdenum oxides [7] and heteropolyacids [8]). In some cases, a third component was added to improve the role of the metallic species [9-12]. Due to the strong and amenability to "molecular tuning" acidity (through their salts), the heteropolyanions (HPA), which are highly organized systems, are very good candidates for co-catalyze n-alkane isomerization. Unfortunately, the Keggin structure can be easily destroyed when HPA are not protected. Ono and coworkers appear to be the first to incorporate palladium as metallic species to prevent such destruction [1] and, on the other hand, we have previously shown that cerium is capable to prevent the poisoning during some hydrogen treatments [13]). Moreover, very few works deal with the role and the influence of the content of each component in a mixture of metallic oxide and HPA. Thus, this work describes the results obtained on various mixed oxides and different HPA in a mechanical mixture and focus on the specific role of each component for the n-hexane isomerization.

\section{Experimental}

Heterophosphotungstic acid (HPW), heterosilicotungstic ( $\mathrm{HSiW})$ and heteroborotungstic (HBW) acids were prepared in a classical way [14]. Silicasupported hetropolyacids were prepared by the wet impregnation method. Ce-Ni oxides were prepared by the reverse homogeneous co-precipitation method as described in the literature [15]. Cerium nitrate $\mathrm{Ce}\left(\mathrm{NO}_{3}\right)_{2} \cdot 6 \mathrm{H}_{2} \mathrm{O}$ (Prolabo $\mathrm{Co}$ ) solution $\left(0.5\right.$ mol. $\left.\mathrm{L}^{-1}\right)$ and nickel nitrate $\mathrm{Ni}\left(\mathrm{NO}_{3}\right)_{2} .6 \mathrm{H}_{2} \mathrm{O}$ (Prolabo Co) solution $(0.5$ mol. $\left.\mathrm{L}^{-1}\right)$ were prepared separately and then mixed. The mixed solutions were added dropwise to an excess of potassium hydroxide $\mathrm{KOH}$ (Prolabo Co) solution $\left(0.5 \mathrm{~mol}^{-\mathrm{L}^{-1}}\right)$ under strong stirring. After filtration, the precipitates formed were washed with hot water $(335 \mathrm{~K})$ to eliminate $\mathrm{K}^{+}$until the $\mathrm{pH}$ value of the washing solution decreased from approximatly 11 to 7 . The compounds were dried in an oven at $373 \mathrm{~K}$ for 12 hours, ground and calcined in air for 4 hours at $673 \mathrm{~K}$ with a heating rate of $2 \mathrm{~K} \cdot \mathrm{min}^{-1}$. The Ce-Pd oxides were prepared in the same manner from $\mathrm{Pd}\left(\mathrm{NO}_{3}\right)_{2} .6 \mathrm{H}_{2} \mathrm{O}$ (Prolabo Co) solution $(0.5$ mol. $\left.\mathrm{L}^{-1}\right)$. The samples placed into a flow reactor (U-type glass) were first reduced, at $498 \mathrm{~K}$ and $553 \mathrm{~K}$ for Ni-Ce-O and Pd-Ce$\mathrm{O}$ respectively, for $4 \mathrm{~h}$ in hydrogen with a flowing rate of $21.8 \mathrm{ml} . \mathrm{min}^{-1}$ under atmospheric pressure, and then their catalytic properties were evaluated under the same conditions but hydrogen passed through a saturated containing n-hexane $\left(\mathrm{WWH}=0.36 \mathrm{~h}^{-1}\right)$. The products were analyzed by gas chromatography [16].

\section{Results and discussion}

Owing to their very low surface area, pure heteropolyacids have a very poor activity. Thus, supported HPA, more particularly on silica, are used [17]. The conversion increases remarkably with the HPA loading although it remains low (table1). Unfortunately, the isomerization selectivity decreases simultaneously but, the yield of the C6 isomers and the ratio of the dimethyl butanes (DMB), by respect to the total amounts of the branched alkanes (dimethyl butanes -DMB- plus methyl pentanes -MP-) increase a little bit.

The main drawback of the silica-supported HPA alone is the rapid poisoning of the solid on time. As an example, after $22 \mathrm{~min}$ of reaction time, the conversion is already divided by a factor 4 (table2).

This deactivation, on HPA and their salts, was previously observed by Guisnet et al [18] who assume that this one is related to 
Table1. Isomerization of $\mathrm{n}$-hexane over x wt $\% \mathrm{HPW} / \mathrm{SiO}_{2}$ after 5 min on stream at $498 \mathrm{~K}$.

\begin{tabular}{|c|c|c|c|c|c|}
\hline $\mathrm{x}$ & $10 \mathrm{wt} \%$ & $20 \mathrm{wt} \%$ & $30 \mathrm{wt} \%$ & $40 \mathrm{wt} \%$ & $50 \mathrm{wt} \%$ \\
\hline$\%$ conversion & 3.7 & 5.6 & 16.6 & 17.3 & 28 \\
\hline$\%$ isomerization & 78 & 76.7 & 68 & 63.3 & 55.9 \\
\hline DMB/(DMB+MP) \% & 15.9 & 15.6 & 17 & 18 & 9 \\
\hline C6 isomers yield \% & 2.9 & 4.3 & 11.3 & 11 & 15.6 \\
\hline
\end{tabular}

$\mathrm{DMB}=$ dimethyl butanes, $\mathrm{MP}=$ methyl pentanes

Table2. Isomerization of $\mathrm{n}$-hexane over $40 \mathrm{wt} \% \mathrm{HPW} / \mathrm{SiO}_{2}$ on stream at $498 \mathrm{~K}$.

\begin{tabular}{|c|c|c|c|}
\hline Time $(\min )$ & 5 & 22 & 57 \\
\hline \% Conversion & 17.3 & 4.4 & 2.6 \\
\hline \% isomerization & 63.3 & 78.2 & 78.9 \\
\hline DMB/(DMB+MP) \% & 18 & 16 & 14 \\
\hline C6 isomers yield \% & 11 & 3.5 & 2 \\
\hline
\end{tabular}

$\mathrm{DMB}=$ dimethyl butanes, $\mathrm{MP}=$ methyl pentanes

a coke formation but these authors worked in absence of hydrogen which is known to preserve a little this formation. Nevertheless, only presence of hydrogen is clearly not sufficient to avoid poisoning in our case. One alternative to correct these drawbacks is to add a co-catalyst capable to avoid the poisoning and to protect the highly organized catalytic system (viz: HPA). On the other hand, it is well known that isomerization reaction is easier in presence of a bifunctional catalyst [1] with one acidic function and one hydrogenating/dehydrogenating function; if HPA, which exhibit a strong acidity, are good candidates for the former function, a metallic species must be an excellent candidate for the second one. Presence of cerium was also proved to be favorable to prevent sulfur poisoning during hydrotreating reactions [13]. Ono and coworkers appear to be the first to incorporate palladium as a cation for the isomerization of n-alkanes[19] and it was previously reported that the reduced $\mathrm{Ce}-\mathrm{Ni}$ mixed oxides could be used as promoters for the hydrogenation reactions[20]. So, we undertook the study of each component of a complex mixture to know what are the specific role of each active species, and the value of their optimal content. The table 3 displays the results obtained with mechanical mixtures of $\mathrm{HPA} / \mathrm{SiO}_{2}$ and $\mathrm{Ni}_{\mathrm{x}} \mathrm{Ce}$ oxide or $\mathrm{Pd}_{\mathrm{y}} \mathrm{Ce}$ oxide were $\mathrm{x}$ and $\mathrm{y}$ are the atomic ratio $\mathrm{Me} / \mathrm{Ce}$. No deactivation was observed, even after $4 \mathrm{~h}$ on stream. As expected, the only presence of cerium does not play an important role for the activity but prevent the poisoning of the HPA as, in absence of $\mathrm{Ce}$, the activity decreases on time. Thus, the cerium, probably, is an electronic promoter due to the $\mathrm{Ce}^{4+} / \mathrm{Ce}^{3+}$ Red-Ox system which improves the rate of the reducibility of the nickel and palladium ions during the reaction. We have to recall that when the metallic species used is platinum, we do no longer observe poisoning, even in absence of cerium [8]. Misono et al [21] observed the same absence of deactivation on a mechanical mixture of $\mathrm{Pt} / \mathrm{SiO}_{2}-\mathrm{HPW}$ cesium salt or sulfated zirconia or zeolite $\beta$ as soon as the hydrogen pressure reached 0.2 atm. Concerning the ratio $\mathrm{Ni} / \mathrm{Ce}$, surprisingly, it appears little influencing the level of conversion when we double this ratio; but we observe an effect on the 
Table3. Effect of the ratio $\mathrm{Me} / \mathrm{Ce}$ on the catalytic properties of the mechanical mixture of $\mathrm{Me}-\mathrm{Ce}-\mathrm{O}$ and $\mathrm{HPW} / \mathrm{SiO}_{2}$

\begin{tabular}{|c|c|c|}
\hline Ni/Ce ratio* & 1 & 2 \\
\hline$\%$ conversion & 27.7 & 26.2 \\
\hline$\%$ isomerization & 91.2 & 96 \\
\hline DMB/(DMB+MP) \% & 17.9 & 15.1 \\
\hline C6 isomers yield \% & 25.3 & 25.1 \\
\hline
\end{tabular}

\begin{tabular}{|c|c|c|c|c|c|}
\hline Pd/Ce ratio** & 0 & 0.05 & 0.1 & 0.15 & 0.2 \\
\hline \% Conversion & $13.3 * * *$ & 26.4 & 56.2 & 49.8 & 39 \\
\hline \% isomerization & 93.2 & 99.2 & 98.2 & 98.6 & 98.9 \\
\hline DMB/(DMB+MP) \% & 14 & 9.5 & 14.4 & 11.1 & 8.9 \\
\hline C6 isomers yield \% & 12.4 & 26.2 & 55.2 & 49.1 & 36.6 \\
\hline
\end{tabular}

*mixture of $20 \% \mathrm{Ni}_{\mathrm{x}} \mathrm{CeO}-80 \% \quad\left(50 \mathrm{wt} \% \mathrm{HPW} / \mathrm{SiO}_{2}\right)$, **mixture of $50 \% \mathrm{Pd}_{\mathrm{y}} \mathrm{CeO}-50 \%$ $\left(20 \mathrm{wt} \% \mathrm{HPW} / \mathrm{SiO}_{2}\right)$, *** conversion after few minutes. DMB $=$ dimethyl butanes, $\mathrm{MP}=$ methyl pentanes

amount of DC6 obtained and the value of 1 appears the right ratio. The activity is more sensible to the ratio $\mathrm{Pd} / \mathrm{Ce}$ as we can multiply by a factor 2 the activity, the best ratio seems to be 0.1 .

XRD patterns of fresh and reduced solids are very interesting. For fresh $\mathrm{Ni}-\mathrm{Ce}$ oxides we observe the XRD patterns of both $\mathrm{NiO}$ and $\mathrm{CeO}_{2}$ compounds but the sample reduced at $498 \mathrm{~K}$ shows new peaks which can be assigned to $\mathrm{Ni}^{0}$ while the peaks of the $\mathrm{NiO}$ crystal disappear suggesting that most of the nickel oxide has been reduced in metallic species [12]. An identical result is observed with the mixed $\mathrm{Pd}-\mathrm{Ce}$ oxide: simultaneous presence of $\mathrm{PdO}$ and $\mathrm{CeO}_{2}$ on the fresh oxide and of $\mathrm{Pd}^{0}$ after reduction at $553 \mathrm{~K}$ [11]. Thus, $\mathrm{Ni}^{0}$ and $\mathrm{Pd}^{0}$ species are the active hydrogenating species for the n-hexane isomerization and, probably, the lower efficiency of nickel for such a reaction, partly due to the lower reaction temperature, can also be explained by the different behavior of the $\mathrm{Me} / \mathrm{Ce}$ ratio. Thus, The ratio 1 and 0.1 for $\mathrm{Ni} / \mathrm{Ce}$ and $\mathrm{Pd} / \mathrm{Ce}$ respectively were chosen to pursue the studies.

The respective amounts of the mixed oxide and of HPA influence also the n-hexane reaction activities. For the nickel-based mixed oxide, the optimal amount of $\mathrm{NiCe}$ is $30 \%$ (table 4a), which does not corresponds exactly to the higher value of DC6 obtained while for the Pd-based oxide, the best mixture is constituted of $50 \%$ of $\mathrm{Pd}_{0.1} \mathrm{CeO}$ (table $4 \mathrm{~b}$ ) which corresponds to the larger DC6 percentage.

The figure 1 displays the n-hexane conversion versus the $\mathrm{Ni} / \mathrm{Ni}+\mathrm{W}$ (figure 1a) and $\mathrm{Pd} / \mathrm{Pd}+\mathrm{W}$ (figure $1 \mathrm{~b}$ ) atomic ratio. This ratio is really representative of the metallic sites/acidic sites relative amount, and consequently of the magnitude of the synergy phenomenon.

Table4a. Effect of the wt $\%$ of $\mathrm{NiCeO}$ mixed oxide on the catalytic properties of the mechanical mixture of Ni-Ce-O and $\left(20 \mathrm{wt} \% \mathrm{HPW} / \mathrm{SiO}_{2}\right)$.

\begin{tabular}{|c|c|c|c|c|c|c|}
\hline NiCeO wt\% & 10 & 20 & 30 & 40 & 50 & 60 \\
\hline \% conversion & 14.5 & 19.1 & 21.8 & 20.5 & 16.9 & 14 \\
\hline$\%$ isomerization & 86.6 & 87.3 & 80.4 & 76.5 & 50.4 & 41.6 \\
\hline DMB/(DMB+MP) \% & 17 & 15 & 11 & 11 & 9 & 4 \\
\hline C6 isomers yield \% & 12.6 & 16.7 & 17.5 & 15.7 & 8.5 & 5.8 \\
\hline
\end{tabular}


Table4b. Effect of the wt \% of $\mathrm{PdCeO}$ mixed oxide on the catalytic properties of the mechanical mixture of $\mathrm{Pd}-\mathrm{Ce}-\mathrm{O}$ and $\left(20 \mathrm{wt} \% \mathrm{HPW} / \mathrm{SiO}_{2}\right)$.

\begin{tabular}{|c|c|c|c|c|c|}
\hline $\mathrm{Pd}_{0.1} \mathrm{CeO} \%$ & 25 & 40 & 50 & 60 & 75 \\
\hline$\%$ Conversion & 20.8 & 47.8 & 56.2 & 48.7 & 5.7 \\
\hline$\%$ isomerization & 98.9 & 98.5 & 98.2 & 98.5 & 93.7 \\
\hline $\mathrm{DMB} /(\mathrm{DMB}+\mathrm{MP}) \%$ & 6.8 & 13.3 & 14.4 & 13.5 & 4.3 \\
\hline $\mathrm{C}$ isomers yield \% & 20.6 & 47.1 & 55.2 & 48 & 5.3 \\
\hline
\end{tabular}

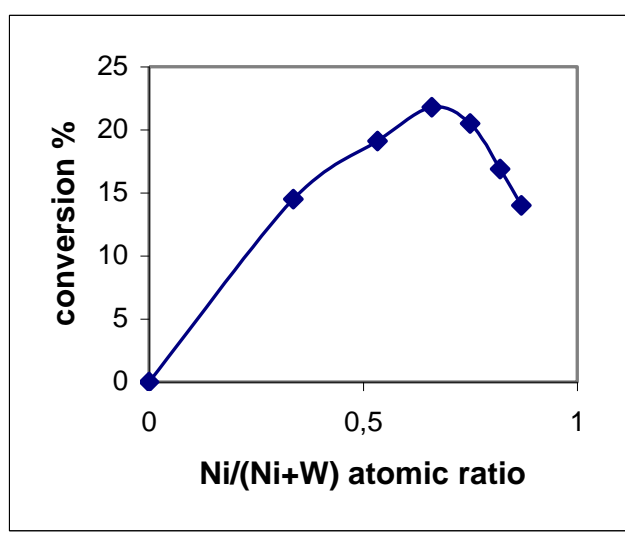

1a



$1 b$

Figure1. n-hexane isomerization conversion versus the tungsten content in the mechanical mixtures of MeCeO-HPW/SiO 2 (1a: NiCeO-20wt $\% \mathrm{HPW} / \mathrm{SiO}_{2} ; 1 \mathrm{~b}: \mathrm{Pd}_{0.1} \mathrm{CeO}-20 \mathrm{wt} \% \mathrm{HPW}$ )

Table5. Effect of the central atom in heteropolyacid for mechanical mixtures

\begin{tabular}{|c|c|c|c|c|c|c|}
\hline HPA & \multicolumn{2}{|c|}{$\mathrm{HPW}$} & \multicolumn{2}{c|}{$\mathrm{HSiW}$} & \multicolumn{2}{c|}{$\mathrm{HBW}$} \\
\hline MeCeO & $\mathrm{NiCeO}^{\mathrm{a}}$ & $\mathrm{Pd}_{0.1} \mathrm{CeO}^{\mathrm{b}}$ & $\mathrm{NiCeO}^{\mathrm{a}}$ & $\mathrm{Pd}_{0.1} \mathrm{CeO}^{\mathrm{b}}$ & $\mathrm{NiCeO}^{\mathrm{a}}$ & $\mathrm{Pd}_{0.1} \mathrm{CeO}^{\mathrm{b}}$ \\
\hline \% Conversion & 27.7 & 56.2 & 23.3 & 47 & 2.1 & - \\
\hline \% isomerization & 91.2 & 98.2 & 94.2 & 99.3 & 67 & - \\
\hline DMB/(DMB+MP) \% & 17.9 & 14.4 & 13.1 & 11.6 & 8 & - \\
\hline C6 isomers yield \% & 25.3 & 55.2 & 22 & 46.7 & 1.4 & - \\
\hline
\end{tabular}

a: mixture of $20 \% \mathrm{NiCeO}-80 \%\left(50 \mathrm{wt} \% \mathrm{HPA} / \mathrm{SiO}_{2}\right)$. b: mixture of $50 \% \mathrm{Pd}_{0.1} \mathrm{CeO}-50 \%($ $20 \mathrm{wt} \% \mathrm{HPA} / \mathrm{SiO}_{2}$ )

For NiCeO-HPW mechanical mixtures, the higher conversion is reached for about $66 \%$ moles of $\mathrm{Ni}$ by respect to the total $(\mathrm{Ni}+\mathrm{W})$, that is to say 2 moles of $\mathrm{Ni}$ per mole of $\mathrm{W}$. For the $\mathrm{Pd}_{0.1} \mathrm{CeO}-\mathrm{HPW}$ mechanical mixtures, the best conversion is obtained with $40 \%$ moles of $\mathrm{Pd}$ by respect to the total $(\mathrm{Pd}+\mathrm{W})$, that means 0.66 mole of Pd per mole of W. Besides, these values can be linked with the number of easily accessible Me centers from or to the acid sites in term of proximity, and is comparable with those previously obtained by Alvarez et al on PtHY catalysts [22] and confirm the best hydrogenating nature of Pd. At this point, it seems interesting to study the influence of the central atom in the well-organized heteropolyacids. The table 5 shows the results obtained with HPW, HSiW and HBW respectively for the two kind of mechanical mixtures.

If the results with the borotungstic acid are definitely and drastically less interesting, 
(we did not try it over $\mathrm{Pd}_{0.1} \mathrm{CeO}$ ), the conversion are in the order:

\section{$\mathrm{HPW}>\mathrm{HSiW}>\mathrm{HBW}$}

which is consistent with the order of their acid strength as claimed in the literature [23]. However, this is not totally true for the isomerization selectivity which, slightly, is better on $\mathrm{HSiW}$, probably because $\mathrm{SiW}_{12} \mathrm{O}_{40}{ }^{4-}$ is a softer base than $\mathrm{PW}_{12} \mathrm{O}_{40}{ }^{3-}$ complexing organic cation to form a stable intermediate.

In summary, we can now precise the role of each metallic species presenting in the catalyst. Cerium component has mainly a protective function avoiding the poisoning of the others elements. This protection origins probably by the $\mathrm{Ce}^{4+} / \mathrm{Ce}^{3+}$ Red-Ox system which reinforces the protection of species as nickel as proposed by Sauvion et al [24]. In our reactions conditions, the main reaction products are methyl pentanes (MP) and dimethyl butanes (DMB). Guisnet et al [18] assume that, on pure HPA cesium salt, 2,3-DMB and MP are primary products formed by an intramolecular isomerization of a classical carbenium ion coming through a monomolecular mechanism. In the presence of a metallic species, the classical bifunctionnal mechanism is well admitted and explained in [21] justifying the necessary close proximity of the metal centers and of the acid sites for allowing the spill over of, either the hydrogen species or the one of the intermediates In this latter case, nickel and palladium, both in the metallic state, are the hydrogenating/dehydrogenating function and provide an important synergetic effect to HPA for the global transformation. The only requirement for such a synergy is a sufficient amount of the $\mathrm{Me}^{0}$ species and a good dispersion of the various active species on the support. For the former condition, an amount of $2 \mathrm{Ni}^{0}$ atom and $0.66 \mathrm{Pd}^{0}$ atom respectively per tungsten atom appears as optimal for the two different mixed oxides (i.e. $\mathrm{NiCeO}$ and $\mathrm{Pd}_{0.1} \mathrm{CeO}$ ), and for the second condition, we can reasonably assumr that the 30-70 and the 50-50 mixtures are homogeneous. Besides, the tries with co-impregnated $\mathrm{Pd}_{\mathrm{x}} \mathrm{CeO}-\mathrm{HPA} / \mathrm{SiO}_{2}$ give rise to the same range of order of conversion [2]. The last result is on the type of central atom for the HPA; we observe a higher activity with HPW than with HSiW or HBW. This is simply related to the acidic strength.

\section{Conclusion}

Mechanical mixtures of mixed Me-Ce oxides $(\mathrm{Me}=\mathrm{Ni}, \mathrm{Pd})$ and silica-supported heteropolyacids $(\mathrm{HPA}=\mathrm{HPW}, \mathrm{HSiW}$, HBW) have a beneficial effect on the nhexane isomerization to branched alkanes. The primary beneficial effect, in term of synergism on the activity, can be explained by the more or less close proximity of the two important functions (i.e. hydrogenating/dehydrogenating function on the metallic species coming from the reduced mixed oxides and the acidic properties of the silica-supported heteropolyacid). The secondary beneficial effect is also important, more particularly for the Ni-based system; firstly, the Keggin structure, which is a highly organized structure, is maintained and secondly, the sensibility to coke deposition, and consequently to the decrease of the activity by poisoning, is totally inhibited. Thus a whole study of the best type of the different metallic species and of their optimal content shows that the best mixture is: $50 \mathrm{wt} \%$ of $\mathrm{Pd}_{0.1} \mathrm{Ce}$ oxide and $50 \mathrm{wt} \%$ of $\left(20 \mathrm{wt} \% \mathrm{HPW} / \mathrm{SiO}_{2}\right)$.

\section{Acknowledgments}

The financial support of CNRS is gratefully acknowledged.

\section{References}

1. Ono Y., Catal.Today, 2003, vol. 81, p. 3. 
2. Zhang A., Nakamura I., Aimoto K. and Fujimoto K., Ind. Eng. Chem. Res., 1995, vol. 34; p. 1074.

3. Zhang A., Nakamura I. and Fujimoto K., Stud. Surf. Sci and Catal., 1997, vol. 112, p. 391.

4. Vasina T.V., Masloboishchikova O.K., Khelkovskaia-Sergeera E.G., Kustov L.M. and Houzvicka J.I., Stud. Surf. Sci and Catal., 2001, vol. 138, p. 93.

5. Pope T.D., Kriz J.F.,.Stanciulescu M and Monnier J., Appl.Catal., 2002, vol. 233, p. 45.

6. Yadav G.D. and Nair J.J., Microporous and mesoporous materials, 1999, vol. 33, p. 1.

7. Matsuda T., Sakagami M. and Takahashi N., Catal.Today, 2003, vol. 81, p. 31.

8. Kuang W., Rives A., Fournier M. and Hubaut R., Catal.Lett., 2002, vol.79, p. 133.

9. Eswaramoorthy I. and Lingappan N., Appl.Catal., 2003, ser. A, vol. 245, p. 119.

10. Saberi M.A. and Levanmao R., Appl.Catal., 2003, ser.A, vol. 242, p. 139.

11. Hubaut R., Ouled ben Tayeb B., Rives A. and Fournier M., Solid.State Ionics, In press.

12. Kuang W., Rives A., Ouled ben Tayeb B., Fournier M. and Hubaut R., J. Colloid Interface Sci., 2002, vol. 248, p. 123.

13. Kherbech A., Benhareff A.and Hubaut R., React.Kinet.Catal.lett., 1996, vol. 57, p. 13.
14. Rocchioli-Deltcheff C., Fournier M., Franckand R. and Thouvenot R., Inorg.Chem., 1982, vol. 22, p. 207.

15. Wrobel G., Lamonier C., Benani A., D'Huysser A. and Aboukais A., J.Chem.Soc.Faraday trans., 1996, vol. 92, p.2001.

16. Kuang W., Rives A., Fournier M. and Hubaut R., Appl.Catal., 2003, ser.A, vol. 250, p. 221.

17. Izumi Y., Hasebe R. and Urabe K., J.Catal., 1983, vol. 84, p. 402.

18. Guisnet M., Bichon Ph., Gnep N.S and Essayem N., Topics in Catal., 2000, vol. 11/12, p. 247.

19. Suzuki S., Kogai K. and Ono Y., Chem.Lett., 1984, vol. 5, p. 699.

20. Lamonier C., Ponchel A., D’Huysser A. and Jalowiecki-Duhamel L., Catal.Today, 1999, vol. 50, p. 247.

21. Liu Y., Koyano G. and Misono M., Topics in Catal., 2000, vol. 11/12, p. 239.

22. Alvarez F., Ribeiro F.R., Perot G., Thomazeau C. and Guisnet M., J.Catal., 1996, vol. 62, p. 179.

23. Okuchara T., Mizuno N. and Misono M., Adv.Catal., 1996, vol. 41, p. 113.

24. Sauvion G.N., Tempere J.F., Guilleux M.F., Djega-Mariadassou G. and Delafosse D., Appl.Catal., 1987, vol. 39, p. 132.

25. Ouled ben Tayeb B., Kuang W., Rives A., Fournier M. and Hubaut R., Proceedings of XVIII Simposium IberoAmericano de catalysis ,Porlamar(Venezuela), 2002, p. 911. 